\title{
Serum Vitamin D Levels in Fertile and Infertile Women with Polycystic Ovary Syndrome
}

\section{Vitamin-D-Spiegel in fertilen und infertilen Frauen mit polyzystischem Ovarsyndrom}

(우 (1) (옹 $\ominus$

\author{
Authors \\ Affiliation \\ Zekai Tahir Burak Woman's Health Education and Research \\ Hospital, Ankara, Turkey
}

Demet Kokanalı, Mujdegul Karaca, Gulnur Ozakşit, Burak Elmas, Yaprak Engin Üstün

Key words

hormones, infertility, ovary

Schlüsselwörter

Hormone, Infertilität, Ovar

$\begin{array}{ll}\text { received } & 31.8 .2018 \\ \text { revised } & 30.12 .2018 \\ \text { accepted } & 31.12 .2018\end{array}$

Bibliography

DOI https://doi.org/10.1055/a-0828-7798

Published online 29. 3. 2019 | Geburtsh Frauenheilk 2019; 79: 510-516 @ Georg Thieme Verlag KG Stuttgart · New York । ISSN 0016-5751

Correspondence

Dr. Demet Kokanalı

Zekai Tahir Burak Woman's Health Education and Research

Hospital

Talatpasa Bulvari, 06100 Ankara, Turkey

demetkokanali@gmail.com

\section{ABSTRACT}

Introduction In polycystic ovary syndrome, serum vitamin D levels are known to correlate with metabolic conditions such as diabetes mellitus, metabolic syndrome and cardiovascular disease. However, there are not enough studies showing such a relationship with female fertility. We aimed to compare serum vitamin D levels in fertile and infertile women with polycystic ovary syndrome to evaluate whether vitamin D may play a role in the pathogenesis of fertility problems in women with polycystic ovary syndrome.

Materials and Methods 274 infertile and 111 fertile women with polycystic ovary syndrome were included in this retrospective study. Infertile and fertile groups were matched by age, body mass index and homeostasis model assessment of insulin resistance. Anthropometric, clinical and laboratory characteristics of the women were recorded. Serum 25 $(\mathrm{OH}) \mathrm{D}_{3}$ levels were used to assess serum vitamin $\mathrm{D}$ levels.

Results No significant differences were detected between groups in terms of anthropometric, clinical and laboratory features except for serum $25(\mathrm{OH}) \mathrm{D}_{3}$ levels and the incidence of vitamin $\mathrm{D}$ deficiency. Vitamin $\mathrm{D}$ levels were significantly lower and vitamin D deficiency was more common in the infertile group compared to the fertile group. When the groups were stratified into obese/non-obese or insulin resistance positive/negative, infertile obese and infertile insulin resistancepositive women had the lowest serum $25(\mathrm{OH}) \mathrm{D}_{3}$ levels.

Conclusion Serum vitamin D levels are lower in infertile women with polycystic ovary syndrome compared to fertile women. When insulin resistance or obesity was present, vitamin D levels were reduced further. Thus, in polycystic ovary syndrome, lower vitamin D levels may play a role in the pathogenesis of fertility problems.

\section{ZUSAMMENFASSUNG}

Einleitung Bekanntlich sind Vitamin-D-Spiegel in Frauen mit polyzystischem Ovarsyndrom mit Stoffwechselkrankheiten wie Diabetes mellitus, metabolisches Syndrom und HerzKreislauf-Erkrankungen korreliert. Es gibt aber bislang zu wenig Studien über den Zusammenhang zwischen Vitamin D und weiblicher Fertilität. Ziel unserer Studie war es, den Vitamin-D-Spiegel bei fruchtbaren und unfruchtbaren Frauen mit polyzystischem Ovarsyndrom zu messen, um herauszufinden, ob Vitamin D eine Rolle bei der Pathogenese von Infertilität in Frauen mit polyzystischem Ovarsyndrom spielt.

Material und Methoden Insgesamt wurden 274 infertile und 111 fertile Frauen mit polyzystischem Ovarsyndrom in dieser retrospektiven Studie eingeschlossen. Die infertilen und fertilen Gruppen waren hinsichtlich Alter, Body-Mass-Index und HOMA-Index (Insulinresistenz) vergleichbar. Anthropometrische, klinische und Labormerkmale der Frauen wurden erfasst. Der $25(\mathrm{OH}) \mathrm{D}_{3}$-Spiegel wurde zur Beurteilung des Vitamin-D-Spiegels verwendet. 
Ergebnisse Mit Ausnahme des $25(\mathrm{OH}) \mathrm{D}_{3}$-Spiegels und Vitamin-D-Mangels gab es keine signifikanten Unterschiede zwischen den Gruppen in Bezug auf anthropometrische, klinische und Labormerkmale. Verglichen mit der fertilen Gruppe war der Vitamin-D-Spiegel signifikant niedriger in der infertilen Gruppe, und Vitamin-D-Mangel trat in dieser Gruppe häufiger auf. Es wurde eine weitere Unterteilung der Gruppen in übergewichtige/nicht übergewichtige und insulinresistente/nicht insulinresistente Frauen vorgenommen. Unfruchtbare über- gewichtige Frauen und unfruchtbare insulinresistente Frauen hatten die niedrigsten $25(\mathrm{OH}) \mathrm{D}_{3}$-Werte.

Schlussfolgerung Verglichen mit fruchtbaren Frauen waren die Vitamin-D-Werte von infertilen Frauen mit polyzystischem Ovarsyndrom niedriger. Kam noch Insulinresistenz oder Fettleibigkeit dazu, waren die Vitamin-D-Werte noch niedriger. Bei Frauen mit polyzystischem Ovarsyndrom spielen niedrigere Vitamin-D-Werte möglicherweise eine Rolle bei der Pathogenese von Fertilitätsproblemen.

\section{Introduction}

Infertility is an important issue in public health. It affects approximately 48.5 million couples worldwide and has significant psychological, medical and economic consequences [1]. Polycystic ovary syndrome (PCOS) is the most common endocrinopathy in approximately 9 to $18 \%$ of women of reproductive age and the leading cause of female infertility [2,3]. The etiology of PCOS is not fully understood and is probably the result of a complex interaction of environmental and genetic factors. Insulin resistance (IR) and hyperandrogenism have been shown to be key pathophysiological mechanisms. Clinically, PCOS may be associated with reproductive (hyperandrogenism, menstrual irregularity, oligo-ovulation or anovulation, infertility), metabolic (dyslipidemia, type 2 diabetes, cardiovascular risk factors) and psychological symptoms (depression, anxiety, lower quality of life) and can be a major health burden [4].

Vitamin $D$ is a steroid hormone synthesized by the skin when exposed to ultraviolet light. A small amount of total vitamin D is obtained through diet and/or supplements. The main biological function in the human body is to protect calcium homeostasis and promote bone mineralization. It also affects a variety of functions such as cell differentiation, apoptosis, antiproliferation, immunosuppression and anti-inflammation. Vitamin D carries out all these functions mainly through vitamin $D$ receptors. Vitamin $D$ receptors have not only been detected in calcium regulatory tissues such as the intestines and the skeletal and parathyroid glands but also in many other reproductive organs such as the ovaries (especially granulosa cells), uterus, placenta, testis, hypothalamus and the pituitary gland [5]. This has been interpreted as vitamin D having some effect on reproductive processes in women and men [6]. PCOS women have a higher risk of vitamin D deficiency. The prevalence of vitamin $\mathrm{D}$ deficiency in the general adult population is $20-48 \%$, while the prevalence in PCOS women is $67-85 \%$ [7]. Several studies have been conducted in this context to investigate the relationship between vitamin D status and well-known PCOS comorbidities. Most studies have focused on vitamin D and metabolic conditions and reported that low levels of vitamin $D$ are associated with an increased risk of type 2 diabetes, IR, metabolic syndrome and cardiovascular disease [8,9]. However, there are not enough studies that show the relationship with female fertility. Therefore, we aimed to compare serum vitamin D levels in fertile and infertile women with polycystic ovary syndrome to evaluate whether vitamin D may play a role in the pathogenesis of fertility problems in women with polycystic ovary syndrome.

\section{Materials and Methods}

\section{Study design and population}

This retrospective case-control study was conducted in Zekai Tahir Burak Women's Health Education and Research Hospital, a tertiary, referral teaching and research hospital in Ankara, the capital city of Turkey. Women diagnosed with PCOS and referred to the Reproductive Endocrinology and Infertility Department because of complaints related to PCOS over a 2 year-period were enrolled in the study. The Institutional Review Board of the hospital approved the study. Due to the retrospective design of the study, informed consent was not obtained from the subjects.

For all participants, the diagnosis of PCOS was made by expert gynecologists based on the Rotterdam criteria, i.e., two out of three of the following features were required for a confirmation of the diagnosis:

1. oligo-ovulation and/or anovulation,

2. clinical and/or biochemical signs of hyperandrogenism, and

3. the presence of polycystic ovaries on ultrasound examination [4].

Hyperprolactinemia, thyroid dysfunction, and specific adrenal disorders were excluded clinically and, if necessary, biochemically. The case group consisted of infertile women with PCOS. Infertile women with PCOS were women who had tried to become pregnant but were unable to conceive despite at least 1 year of unprotected sexual intercourse. All of the women had not previously had any infertility treatment. Their tubes were open and the uterine cavity was normal in size as measured by hysterosalpingography. Their husbands also had normal spermiograms (with a sperm concentration of at least 15 million per milliliter, a motility of more than $40 \%$ and a morphology of more than $4 \%$ normal forms). The control group consisted of women with PCOS who had a biochemically confirmed pregnancy at the time of referral to the department for menstrual irregularity. None of these women received infertility treatment. Pregnant women whose pregnancy would not be able to reach 20 weeks of gestation were excluded from the control group. The case and control groups were matched by age, body mass index (BMI) and homeostasis model assessment of insulin resistance (HOMA-IR). Women who were older than 35 years, smoked, had a history of any systemic disease (i.e., hypertension, diabetes or cardiovascular disease), had previously taken vitamin D supplements, had taken oral contraceptives, glucocorticoids, antiandrogens, ovulation induction agents, 
antidiabetic or antiobesity drugs, or other hormonal drugs in the previous 6 months or had other concurrent medical illnesses (i.e., renal disease or malabsorptive disorders) were excluded from the study.

\section{Anthropometric, clinical and laboratory data}

All the data in the study were obtained from hospital records. Women with insufficient data were also excluded. Standard anthropometric data (height, weight, waist circumference [WC] and hip circumference [HC]), systolic and diastolic blood pressure) of each participant were recorded. $\mathrm{HC}$ was measured as the widest circumference at the level of the buttocks. WC was measured as the smallest circumference at the level of umbilicus. Waist-tohip ratio (WHR) was calculated by dividing WC by HC. BMI was calculated as weight/height ${ }^{2}\left(\mathrm{~kg} / \mathrm{m}^{2}\right)$. A Ferriman-Gallwey score was used to evaluate the degree of hirsutism [10]. Blood samples to determine hormonal (total testosterone, free testosterone, dehy- droepiandrosterone sulfate, sex hormone-binding globulin [SHBG], luteinizing hormone [LH], follicle-stimulating hormone [FSH], LH/FSH ratio, estradiol, prolactin, thyroid-stimulating hormone, anti-Mullerian hormone $[\mathrm{AMH}], 25(\mathrm{OH}) \mathrm{D}_{3}$ ) and metabolic (fasting glucose, fasting insulin, total cholesterol, high-density lipoprotein cholesterol, low-density lipoprotein cholesterol, triglycerides) parameters were collected from the antecubital vein between 8:00 and 9:00 a. m. after at least 8 hours of fasting, preferably in the early follicular phase of the menstrual cycle (2nd or 3rd day) from both cases and controls. IR was estimated using the HOMA-IR (calculated as fasting plasma insulin in $\mu \mathrm{U} / \mathrm{ml} \times$ fasting plasma glucose in mmol/L divided by 22.5) [11]. The free androgen index (FAl) was calculated as testosterone $(\mathrm{nmol} / \mathrm{L}) / \mathrm{SHBG}$ $(\mathrm{nmol} / \mathrm{L}) \times 100[12]$.

Serum $25(\mathrm{OH}) \mathrm{D}_{3}$ levels were used to assess serum vitamin $D$ levels, because $25(\mathrm{OH}) \mathrm{D}_{3}$ levels reflect both dietary intake and skin-synthesized vitamin $D$ levels and do not change during the

- Table 1 Clinical characteristics of infertile and fertile women with PCOS.

\begin{tabular}{|c|c|c|c|}
\hline & Infertile group $(n=274)$ & Fertile group $(n=111)$ & p \\
\hline Age (years) & $25.01 \pm 3.58$ & $25.47 \pm 2.96$ & 0.238 \\
\hline $\operatorname{BMI}\left(\mathrm{kg} / \mathrm{m}^{2}\right)$ & $27.57 \pm 6.74$ & $27.38 \pm 6.57$ & 0.725 \\
\hline Waist-to-hip ratio & $0.83 \pm 0.06$ & $0.81 \pm 0.07$ & 0.596 \\
\hline Systolic blood pressure (mmHg) & $110.4 \pm 9.1$ & $111.8 \pm 15.1$ & 0.689 \\
\hline Diastolic blood pressure $(\mathrm{mmHg})$ & $71.9 \pm 5.6$ & $70.5 \pm 8.6$ & 0.752 \\
\hline Ferriman-Gallwey score & $8.66 \pm 4.90$ & $9.15 \pm 5.08$ & 0.462 \\
\hline Fasting blood glucose (mg/dl) & $91.24 \pm 8.26$ & $92.16 \pm 9.86$ & 0.346 \\
\hline Fasting insulin $(\mu \mathrm{l} \mathrm{U} / \mathrm{ml})$ & $13.94 \pm 8.28$ & $12.80 \pm 7.01$ & 0.263 \\
\hline HOMA-IR & $3.13 \pm 0.89$ & $3.08 \pm 0.85$ & 0.668 \\
\hline Total cholesterol (mmol/l) & $176.02 \pm 34.54$ & $176.81 \pm 39.38$ & 0.847 \\
\hline High-density lipoprotein (mmol/l) & $54.88 \pm 16.06$ & $53.18 \pm 13.87$ & 0.229 \\
\hline Low-density lipoprotein (mmol/l) & $97.77 \pm 31.98$ & $103.20 \pm 53.38$ & 0.229 \\
\hline Triglycerides (mmol/l) & $125.63 \pm 46.20$ & $133.08 \pm 58.76$ & 0.124 \\
\hline Luteinizing hormone (IU/I) & $9.38 \pm 4.08$ & $8.02 \pm 4.03$ & 0.157 \\
\hline Follicle-stimulating hormone (IU/I) & $5.58 \pm 2.18$ & $5.41 \pm 1.50$ & 0.558 \\
\hline LH/FSH ratio & $1.87 \pm 0.25$ & $1.47 \pm 0.55$ & 0.168 \\
\hline Estradiol (pg/ml) & $46.10 \pm 12.65$ & $40.27 \pm 15.21$ & 0.117 \\
\hline Total testosterone (ng/ml) & $1.43 \pm 0.57$ & $1.38 \pm 0.41$ & 0.447 \\
\hline Free testosterone (pg/ml) & $2.10 \pm 0.77$ & $2.03 \pm 0.81$ & 0.420 \\
\hline Dehydroepiandrosterone sulfate (mg/ml) & $287.71 \pm 123.68$ & $271.60 \pm 115.92$ & 0.263 \\
\hline Sex hormone-binding globulin (nmol/l) & $51.79 \pm 23.79$ & $49.24 \pm 29.66$ & 0.609 \\
\hline Free androgen index & $6.36 \pm 2.92$ & $5.68 \pm 2.73$ & 0.160 \\
\hline Prolactin $(\mu \mathrm{g} / \mathrm{L})$ & $17.59 \pm 7.70$ & $18.00 \pm 8.60$ & 0.465 \\
\hline Thyroid-stimulating hormone (mIU/L) & $2.08 \pm 1.12$ & $2.20 \pm 0.96$ & 0.342 \\
\hline Anti-Mullerian hormone (ng/ml) & $7.92 \pm 4.39$ & $7.54 \pm 4.59$ & 0.561 \\
\hline $25(\mathrm{OH}) \mathrm{D}_{3}(\mathrm{ng} / \mathrm{ml})$ & $11.63 \pm 5.61$ & $15.45 \pm 6.89$ & $<0.001$ \\
\hline Vitamin D deficiency & $236(86.1)$ & $86(77.5)$ & 0.038 \\
\hline \multicolumn{4}{|c|}{ Variables are listed as mean \pm standard deviation and as a percentage (\%). } \\
\hline \multicolumn{4}{|c|}{ BMI: body mass index; HOMA-IR: homeostasis model assessment of insulin resistance. } \\
\hline$p<0.05$ was considered statistically signific & & & \\
\hline
\end{tabular}


menstrual cycle. Thus, it is accepted as the best indicator of vitamin D levels [13]. Serum levels of $25(\mathrm{OH}) \mathrm{D}_{3}$ were measured with an ELISA kit (Immunodiagnostic AG, Germany). The intra- and inter-assay coefficients of variation were 8.9 and $10.6 \%$, respectively, for serum $25(\mathrm{OH}) \mathrm{D}_{3}$. In order to eliminate the effects of time (seasons) on vitamin D levels, women who gave blood samples at similar times were included. All samples were collected in spring when sunlight levels were relatively low in Ankara (longitude: $40^{\circ}$ $40^{\prime} \mathrm{N}$, latitude: $32^{\circ} 34^{\prime} \mathrm{E}$, altitude: $891 \mathrm{~m}$, average temperature: $6.1-16.2^{\circ} \mathrm{C}$ ) [14]. Serum $25(\mathrm{OH}) \mathrm{D}_{3}$ levels of less than $20 \mathrm{ng} / \mathrm{ml}$ were classified as vitamin $\mathrm{D}$ deficiency [15].

\section{Statistical analysis}

Statistical analysis was performed with SPSS software, version 18.0 (IBM, USA). The Kolmogorov-Smirnov method was used to estimate data distribution. Depending on the data distribution, Student's $t$ test for continuous independent variables was used to test differences between groups. $\mathrm{X}^{2}$ test was used for categorical variables. Correlations between the level of $25(\mathrm{OH}) \mathrm{D}_{3}$ and other variables were analysed with Pearson's correlation test. Multivariable logistic regression analysis was performed to evaluate the relationship between serum $25(\mathrm{OH}) \mathrm{D}_{3}$ and specific subgroups classified according to BMI and HOMA-IR levels. Variables were expressed as mean \pm standard deviation or as a number (percentage), and statistical significance was defined as a $p$ value of less than 0.05 .

\section{Results}

\section{Anthropometric, clinical and laboratory characteristics of the study groups}

Based on the exclusion criteria, 128 women were excluded and 385 women with PCOS were selected as the study population. Comparisons of the anthropometric, clinical and laboratory parameters of the fertile and infertile women with PCOS are shown in $>$ Table 1. A total of 274 women were in the infertile group and 111 women were in the fertile group. As the groups were matched for age, BMI and HOMA-IR levels, the parameters of the groups were similar except for serum $25(\mathrm{OH}) \mathrm{D}_{3}$ levels and the incidence of vitamin D deficiency. Infertile PCOS women had lower $25(\mathrm{OH}) \mathrm{D}_{3}$ levels $(11.63 \pm 5.61 \mathrm{ng} / \mathrm{ml})$ and a higher incidence of vitamin D deficiency $(86.1 \%)$ compared to fertile PCOS women $(15.45 \pm 6.89 \mathrm{ng} / \mathrm{ml}$ and $77.5 \%$, respectively).

\section{Associations between serum $25(\mathrm{OH}) \mathrm{D}_{3}$ levels and other parameters}

When all women included in the study were considered, $25(\mathrm{OH}) \mathrm{D}_{3}$ levels correlated negatively with BMI, WHR, HOMA-IR, sex hormone-binding globulin and AMH levels $(r=-0.425, p=0.021$; $r=-0.370, p=0.036 ; r=-0.477, p=0.040 ; r=-0.118, p=0.025$ and $r=-0.356, p=0.016$; respectively) and positively with LH levels $(r=0.187, p=0.047)(\triangleright$ Table 2$)$.

\section{Serum $25(\mathrm{OH}) \mathrm{D}_{3}$ levels of subgroups}

When infertile and fertile PCOS women were stratified into two subgroups according to their BMI $\left(<30 \mathrm{~kg} / \mathrm{m}^{2}\right.$ was classified as
- Table 2 Association between clinical parameters and serum $25(\mathrm{OH}) \mathrm{D}_{3}$ levels.

\begin{tabular}{|c|c|c|}
\hline & $\mathbf{R}$ & p \\
\hline Age & 0.046 & 0.372 \\
\hline $\mathrm{BMI}$ & -0.425 & 0.021 \\
\hline Waist-to-hip ratio & -0.370 & 0.036 \\
\hline Systolic blood pressure & -0.048 & 0.360 \\
\hline Diastolic blood pressure & -0.084 & 0.204 \\
\hline Ferriman-Gallwey score & 0.066 & 0.195 \\
\hline Fasting blood glucose & -0.035 & 0.491 \\
\hline Fasting insulin & -0.146 & 0.071 \\
\hline HOMA-IR & -0.477 & 0.040 \\
\hline Total cholesterol & 0.121 & 0.119 \\
\hline High-density lipoprotein & 0.088 & 0.078 \\
\hline Low-density lipoprotein & 0.076 & 0.145 \\
\hline Triglycerides & 0.002 & 0.965 \\
\hline Luteinizing hormone & 0.187 & 0.047 \\
\hline Follicle-stimulating hormone & -0.071 & 0.263 \\
\hline LH/FSH ratio & 0.147 & 0.099 \\
\hline Estradiol & -0.029 & 0.646 \\
\hline Total testosterone & 0.211 & 0.134 \\
\hline Free testosterone & -0.037 & 0.478 \\
\hline Dehydroepiandrosterone sulfate & -0.117 & 0.131 \\
\hline Sex hormone-binding globulin & -0.118 & 0.025 \\
\hline Free androgen index & 0.158 & 0.093 \\
\hline Prolactin & -0.092 & 0.151 \\
\hline Thyroid-stimulating hormone & -0.036 & 0.496 \\
\hline Anti-Mullerian hormone & -0.356 & 0.016 \\
\hline $\begin{array}{l}\text { BMI: body mass index; HOMA-IR: } \\
\text { of insulin resistance. } \\
\text { r: Pearson's corelation coefficient } \\
\text { p }<0.05 \text { was considered statistica }\end{array}$ & tasis mod & ment \\
\hline
\end{tabular}

non-obese and $\geq 30 \mathrm{~kg} / \mathrm{m}^{2}$ as obese), there was no statistically significant difference between obese $(14.13 \pm 11.88 \mathrm{ng} / \mathrm{ml})$ and nonobese $(15.93 \pm 14.34 \mathrm{ng} / \mathrm{ml})$ women with regard to $25(\mathrm{OH}) \mathrm{D}_{3}$ levels in the fertile group $(p=0.505)$. However, serum vitamin $D$ levels were significantly lower in obese women $(10.67 \pm 5.86 \mathrm{ng} / \mathrm{ml})$ compared to non-obese $(12.62 \pm 5.53 \mathrm{ng} / \mathrm{ml})$ women in the infertile PCOS women $(p=0.041)$. When infertile and fertile PCOS women were grouped according to their HOMA-IR levels as IR positive (HOMA-IR $\geq 2.5$ ) or IR negative (HOMA-IR $<2.5$ ), serum $25(\mathrm{OH}) \mathrm{D}_{3}$ levels were similar for IR negative $(16.96 \pm 6.38 \mathrm{ng} / \mathrm{ml})$ and IR positive $(14.20 \pm 5.06 \mathrm{ng} / \mathrm{ml})$ women in the group of fertile PCOS women $(p=0.311)$. However, in the group of infertile PCOS women, $25(\mathrm{OH}) \mathrm{D}_{3}$ levels were significantly lower in women with IR $(10.48 \pm 5.30 \mathrm{ng} / \mathrm{ml})$ compared to women without IR $(12.84 \pm 5.83 \mathrm{ng} / \mathrm{ml})(\mathrm{p}=0.015)(\triangleright$ Table 3$)$.

When we evaluated the subgroups with regard to vitamin $D$ deficiency using multivariable logistic regression analysis, we 
- Table 3 Comparison of serum $25(\mathrm{OH}) \mathrm{D}_{3}$ levels in subgroups of infertile and fertile PCOS women.

\begin{tabular}{|c|c|c|c|c|c|c|}
\hline & \multicolumn{2}{|l|}{ Infertile } & \multirow[t]{2}{*}{$\mathbf{P}$} & \multicolumn{2}{|l|}{ Fertile } & \multirow[t]{2}{*}{$\mathrm{p}$} \\
\hline & Non-obese & Obese & & Non-obese & Obese & \\
\hline \multirow[t]{2}{*}{$25(\mathrm{OH}) \mathrm{D}_{3}(\mathrm{ng} / \mathrm{ml})$} & $12.62 \pm 5.53$ & $10.67 \pm 5.86$ & 0.041 & $15.93 \pm 14.34$ & $14.13 \pm 11.88$ & 0.505 \\
\hline & $\operatorname{IR}(-)$ & $\operatorname{IR}(+)$ & & $\operatorname{IR}(-)$ & IR (+) & \\
\hline $25(\mathrm{OH}) \mathrm{D}_{3}(\mathrm{ng} / \mathrm{ml})$ & $12.84 \pm 5.83$ & $10.48 \pm 5.30$ & 0.015 & $16.96 \pm 6.38$ & $14.20 \pm 5.06$ & 0.311 \\
\hline $\begin{array}{l}\text { Variables are listed } \\
\text { IR: insulin resistanc } \\
p<0.05 \text { was consid }\end{array}$ & $\begin{array}{l}\text { tandard deviati } \\
\text { cally significan }\end{array}$ & & & & & \\
\hline
\end{tabular}

found that infertile obese women (OR [95\% Cl]: 2.69 [1.02-7.11], $\mathrm{p}=0.045)$ and infertile $\mathrm{IR}(+)$ (OR [95\% Cl]:3.03 [1.31-7.05], $\mathrm{P}=0.010$ ) women were the subgroups with significant vitamin $\mathrm{D}$ deficiency ( $\vee$ Table 4$)$.

\section{Discussion}

In this study, we aimed to evaluate serum vitamin D levels in fertile PCOS women compared to infertile PCOS women. We also investigated whether vitamin $\mathrm{D}$ levels differ in terms of female fertility when IR and obesity are present. The results revealed that serum vitamin D levels were lower in infertile PCOS women compared to fertile women. When IR or obesity was present, vitamin D levels were reduced even further.

There are currently a number of in vitro and in vivo studies showing that there may be a relationship between vitamin $D$ deficiency and ovarian physiology in both humans and animals [5]. In serum, there is a correlation between circulating vitamin D and $\mathrm{AMH}$ levels [16]. AMH is primarily produced by the granulosa cells of small antral and pre-antral ovarian follicles in adult women [17]. Like vitamin D levels, serum AMH levels show seasonal variability, with levels in winter lower than in summer. However, appropriate vitamin $D$ supplements (supplements of vitamin $D_{3}$, not vitamin $D_{2}$ ) may suppress the seasonal changes in $A M H$ levels [18]. This condition strongly indicates that $\mathrm{AMH}$ production in adults may be regulated by vitamin $\mathrm{D}$. In the ovary, AMH inhibits primordial follicle recruitment and the sensitivity of growing follicles to follicle-stimulating hormone (FSH), leading to atresia and the death of follicles containing oocytes [17]. Serum AMH levels are two to three times higher in PCOS women than in ovulatory healthy women [19]. The elevated AMH levels in women with PCOS may reduce the sensitivity of antral follicles to FSH and could therefore lead to follicular arrest. Morover, it has been postulated that in vitamin D-deficient PCOS women, vitamin D supplementation lowers abnormally elevated serum AMH levels, and lower serum AMH levels might potentially improve the ovulatory process by decreasing intrafollicular androgens and increasing follicular sensitivity to FSH in PCOS women [20]. Therefore, serum vitamin D may play an important role in the elimination of ovulatory dysfunction and infertility in PCOS women. Consistent with the literature, the fact that serum vitamin D levels were lower in infertile PCOS women compared to fertile women and the inverse relationship between serum $25(\mathrm{OH}) \mathrm{D}_{3}$ and $A M H$ levels in
- Table 4 Multivariable logistic regression analysis of subgroups evaluating the relationship with vitamin D deficiency.

\begin{tabular}{|l|l|l|}
\hline & OR (95\% Cl) & P \\
\hline Fertile non-obese women & Reference & - \\
\hline Fertile obese women & $0.88(0.36-2.18)$ & 0.786 \\
\hline Infertile non-obese women & $1.35(0.51-3.62)$ & 0.546 \\
\hline Infertile obese women & $2.69(1.02-7.11)$ & 0.045 \\
\hline Fertile IR (-) women & Reference & - \\
\hline Fertile IR (+) women & $1.51(0.60-3.79)$ & 0.377 \\
\hline Infertile IR (-) women & $1.69(0.84-3.41)$ & 0.143 \\
\hline Infertile IR (+) women & $3.03(1.31-7.05)$ & 0.010 \\
\hline $\begin{array}{l}\text { OR: odds ratio; Cl: confidence interval; IR: insulin resistance. } \\
\text { P<0.05 was considered statistically significant. }\end{array}$ \\
\hline
\end{tabular}

our study suggests that vitamin D is important for ovulatory function and fertility in PCOS women.

Obesity is associated with female infertility. In obese women, increased estrogen due to peripheral aromatization of androgens, hyperandrogenism due to IR and hyperinsulinemia disturb the neuroregulation of the hypothalamic-pituitary-gonadal axis. This alteration may lead to impaired ovulatory function and female infertility [21,22]. More than half of all women with PCOS are obese [23]. Many PCOS studies in the literature have shown that vitamin $D$ deficiency is more common in obese PCOS women than in nonobese women and that there is a negative correlation between vitamin D levels and BMI [24-26]. This is probably due to the fact that there is more storage of fat-soluble vitamin $D$ in adipose tissue, which is greater in obese PCOS women. Moreover, obese PCOS women may have more sedentary lifestyle than women who are not obese, i.e., they may spend more time indoors with less exposure to sunlight $[26,27]$. Despite all this available information, it has not been fully proven whether the fertility problems in women with PCOS are the result of obesity, lower vitamin D levels, or both. Neverthless, in our study, serum vitamin D levels were lower in infertile PCOS women than in fertile ones, irrespective of BMI. In addition, in the infertile group, obese women had the lowest vitamin D levels and the group of infertile obese women had the greatest vitamin $\mathrm{D}$ deficiency. These findings suggest that de- 
creased vitamin D levels in PCOS women may be associated with fertility problems, and that this correlation is even higher in the presence of obesity.

IR is a hormonal abnormality and plays a key role in PCOS. It can be related to obesity or can occur independently of it. Many studies have shown an inverse relationship between vitamin D levels and IR, but it is unclear whether vitamin D deficiency and IR coexist in PCOS women or whether the two are casually related [28]. As mentioned above, we found a negative correlation between vitamin D and HOMA-IR levels. Some studies have suggested that vitamin D affects insulin sensitivity, increasing insulin secretion and release and enhancing insulin receptor expression, and may prevent the overproduction of proinflammatory cytokines that are suggested to mediate IR. Therefore, vitamin D deficiency could be a contributing factor for IR, which is a common feature in PCOS. However, the underlying mechanisms require further exploration $[29,30]$. With IR, organs are resistant to insulin and unable to absorb glucose from the bloodstream, leading to high blood sugar levels. Beta cells in the pancreas subsequently increase their production of insulin, further contributing to high blood insulin levels and hyperinsulinemia occurs. Increased insulin promotes ovarian and adrenal androgen biosynthesis and amplifies $\mathrm{LH}$-induced androgen production by theca cells. Insulin also lowers sex hormone-binding globulin levels, thereby increasing bioactive, freely floating androgen levels in the bloodstream. Finally, hyperandrogenism occurs. An excess amount of androgen converts to estrogen. High estrogen levels increase the pituitary gland's secretion of LH. High estrogen also suppresses FSH, causing follicles to develop poorly. Insulin also acts on the granulosa cells of small follicles and amplifies the early response to increased $\mathrm{LH}$, leading to terminal differentiation of granulosa cells in small follicles and resulting in an early arrest of follicular growth which causes anovulation. In addition, hyperinsulinemia may adversely affect endometrial function and environment and result in implantation failure [31]. Thus, IR, which is inversely related to vitamin D levels in women with PCOS, may lead to reproductive problems causing infertility. In our study, the fact that infertile PCOS women with IR had the lowest vitamin D levels and infertile PCOS women with IR were the only group at risk of vitamin D deficiency supports the proposed relation between vitamin D, IR and infertility in PCOS.

Our study has some limitations. Firstly, a retrospective study design may raise doubts in terms of the reliability of the obtained data. For example, weather conditions or individual properties such as length of time spent outside and clothing habits are likely to affect vitamin D synthesis in the skin. Unfortunately, due to the retrospective design, it was not possible to evaluate such factors. Secondly, measuring serum $25(\mathrm{OH}) \mathrm{D}_{3}$ levels only once at the time of PCOS diagnosis and the lack of follow-up of the women does not necessarily reflect vitamin $D$ status throughout the period of infertility. These factors should be considered and taken into account in future studies. Another limitation of our study was that the study population was limited to women from a single geographic region. More studies are needed with other participants from different geographic regions who have different exposures to sunlight. Finally, as our patients were matched for age, BMI and HOMA-IR, our results can only be interpreted for this cohort of women. Our study also has a number of strengths. The relatively large number of cases and well-matched controls made the results and comparisons reliable, as age, BMI and HOMA-IR levels did not affects findings.

\section{Conclusion}

This study shows that vitamin D levels are lower in PCOS women who have a fertility problem, regardless of obesity and IR. Infertile PCOS women who are obese or have IR have even lower vitamin D levels and the likelihood of vitamin D deficiency is greater. Thus, vitamin $\mathrm{D}$ deficiency may play a role in the pathogenesis of fertility problems in PCOS women. However, further future longitudinal cohort studies together with prospective randomized trials are needed to better clarify the role of vitamin D in the pathogenesis of female infertility in PCOS women.

\section{Conflict of Interest}

The authors declare that they have no conflict of interest.

\section{References}

[1] Mascarenhas MN, Flaxman SR, Boerma T et al. National, regional, and global trends in infertility prevalence since 1990: a systematic analysis of 277 health surveys. PLoS Med 2012; 9: e1001356

[2] Balen AH, Morley LC, Misso M et al. The management of anovulatory infertility in women with polycystic ovary syndrome: an analysis of the evidence to support the development of global WHO guidance. Hum Reprod Update 2016; 22: 687-708

[3] Goodarzi MO, Dumesic DA, Chazenbalk G et al. Polycystic ovary syndrome: etiology, pathogenesis and diagnosis. Nat Rev Endocrinol 2011; 7: $219-231$

[4] The Rotterdam ESHRE/ASRM-Sponsored Consensus Workshop Group. Revised 2003 consensus on diagnostic criteria and longterm health risks related to polycystic ovary syndrome (PCOS). Hum Reprod 2004; 19: $41-47$

[5] Irani M, Merhi Z. Role of vitamin D in ovarian physiology and its implication in reproduction: a systematic review. Fertil Steril 2014; 102: 460468.e3

[6] Anagnostis P, Karras S, Goulis DG. Vitamin D in human reproduction: a narrative review. Int J Clin Pract 2013; 67: 225-235

[7] He C, Lin Z, Robb SW et al. Serum Vitamin D Levels and Polycystic Ovary syndrome: A Systematic Review and Meta-Analysis. Nutrients 2015; 7: 4555-4577

[8] Krul-Poel YH, Snackey C, Louwers Y et al. The role of vitamin D in metabolic disturbances in polycystic ovary syndrome: A systematic review. Eur J Endocrinol 2013; 169: 853-865

[9] Wehr E, Pilz S, Schweighofer $\mathrm{N}$ et al. Association of hypovitaminosis D with metabolic disturbances in polycystic ovary syndrome. Eur J Endocrinol 2009; 161: 575-582

[10] Hatch R, Rosenfield RL, Kim MH et al. Hirsutism: implications, etiology, and management. Am J Obstet Gynecol 1981; 140: 815-830

[11] Mathews DR, Hosker JP, Rudenski AS et al. Homeostasis model assessment: Insulin resistance and beta cell function from plasma fasting glucose and insulin concentrations in man. Diabetologia 1985; 28: 412-419

[12] Sartorius G, Ly LP, Sikaris K et al. Predictive accuracy and sources of variability in calculated free testosterone estimates. Ann Clin Biochem 2009; 46: $137-143$ 
[13] EFSA NDA Panel (EFSA Panel on Dietetic Products, Nutrition and Allergies). Scientific opinion on dietary reference values for vitamin D. EFSA Journal 2016; 14: 4547. doi:10.2903/j.efsa.2016.4547

[14] Turkish State Meteorological Service. Official statistics of Ankara. Online: http://www.mgm.gov.tr/veridegerlendirme/il-ve-ilceler istatistik.aspx? m¹/4ANKARA\#sfB; last access: 17.04.2016

[15] Holick MF, Binkley NC, Bischoff-Ferrari HA et al. Evaluation, treatment, and prevention of vitamin D deficiency: an Endocrine Society clinical practice guideline. J Clin Endocrinol Metab 2011; 96: 1911-1930

[16] Merhi ZO, Seifer DB, Weedon J et al. Circulating vitamin D correlates with serum antimullerian hormone levels in late-reproductive-aged women: Women's Interagency HIV Study. Fertil Steril 2012; 98: 228-234

[17] Zec I, Tislaric-Medenjak D, Megla ZB et al. Anti-mullerian hormone: a unique biochemical marker of gonadal development and fertility in humans. Biochem Med (Zagreb) 2011; 21: 219-230

[18] Dennis NA, Houghton LA, Jones GT et al. The level of serum anti-mullerian hormone correlates with vitamin D status in men and women but not in boys. J Clin Endocrinol Metab 2012; 97: 2450-2455

[19] Pigny P, Merlen E, Robert $Y$ et al. Elevated serum level of anti-mullerian hormone in patients with polycystic ovary syndrome: relationship to the ovarian follicle excess and to the follicular arrest. J Clin Endocrinol Metab 2003; 88: 5957-5962

[20] Irani M, Minkoff H, Seifer DB et al. Increases serum levels of the soluble receptor for advanced glycation end products in women with PCOS. J Clin Endocrinol Metab 2014; 99: E886-E890

[21] Giviziez CR, Sanchez EG, Approbato MS et al. Obesity and anovulatory infertility: A review. JBRA Assist Reprod 2016; 20: 240-245

[22] Dağ ZÖ, Dilbaz B. Impact of obesity on infertility in women. J Turk Ger Gynecol Assoc 2015; 16: 111-117
[23] Stepto NK, Cassar S, Joham AE et al. Women with polycystic ovary syndrome have intrinsic insulin resistance on euglycaemic-hyperinsulaemic clamp. Hum Reprod 2013; 28: 777-784

[24] Yildizhan R, Kurdoglu M, Adali E et al. Serum 25-hydroxyvitamin D concentrations in obese and non-obese women with polycystic ovary syndrome. Arch Gynecol Obstet 2008; 280: 559-563

[25] Li HW, Brereton RE, Anderson RA et al. Vitamin D deficiency is common and associated with metabolic risk factors in patients with polycystic ovary syndrome. Metab Clin Exp 2011; 60: 1475-1481

[26] Thomson RL, Spedding S, Buckley JD. Vitamin D in the aetiology and management of polycystic ovary syndrome. Clin Endocrinol 2012; 77: 343-350

[27] Lagunova Z, Porojnicu AC, Lindberg F et al. The dependency of vitamin D status on body mass index, gender, age and season. Anticancer Res 2009; 29: 3713-3720

[28] Joham AE, Teede HJ, Cassar $S$ et al. Vitamin D in polycystic ovary syndrome: Relationship to obesity and insulin resistance. Mol Nutr Food Res 2016; 60: 110-118

[29] Teegarden D, Donkin SS. Vitamin D: emerging new roles in insulin sensitivity. Nutr Res Rev 2009; 22: 82-92

[30] Scragg R, Sowers M, Bell C. Third National Health and Nutrition Examination Survey. Serum 25-hydroxyvitamin D, diabetes, and ethnicity in the Third National Health and Nutrition Examination Survey. Diabetes Care 2004; 27: 2813-2818

[31] Sakumoto T, Tokunaga Y, Tanaka H. Insulin resistance/hyperinsulinemia and reproductive disorders in infertile women. Reprod Med Biol 2010; 9: 185-190 